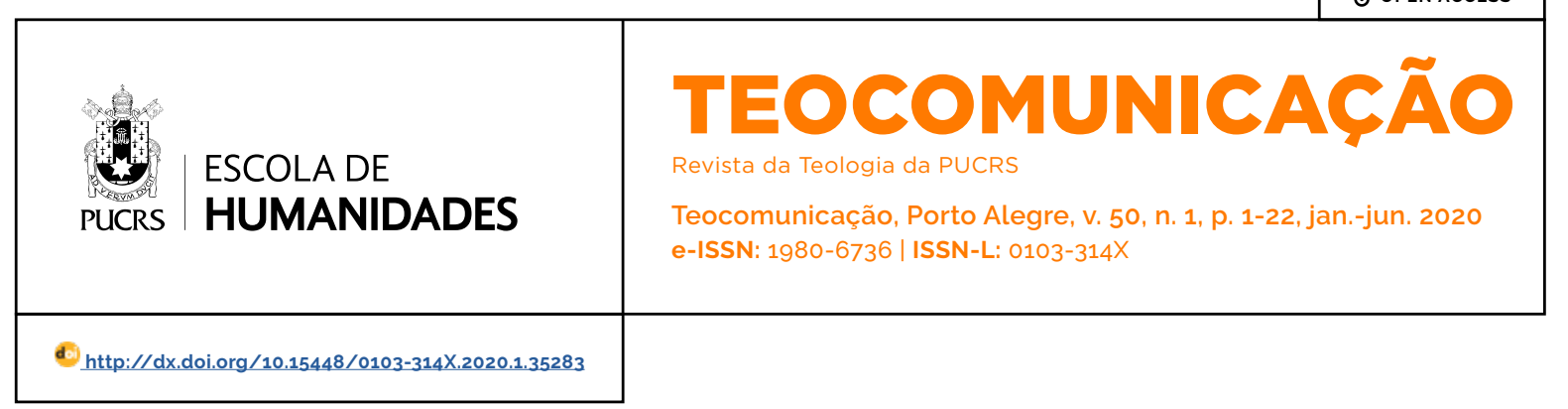

SEÇÃO: ARTIGOS

\title{
Theological Discovery and Future Perspectives of the Dogmatic Datum of the Poor as a Theological Place
}

\author{
Descoberta teológica e perspectivas futuras do dado dogmático do pobre \\ como lugar teológico
}

\section{Ettore Marangi ${ }^{1}$ \\ orcid.org/0000-0001-6525-4712 \\ emarangi@tangaza.ac.ke}

Received on: Aug. $07^{\text {th }}, 2019$ Accepted on: June $01^{\text {st }}, 2020$

\begin{abstract}
There are serious reasons to argue that with Evangelii Gaudium by Pope Francis, the magisterium of the Catholic Church has finally come to fully acknowledge the function of the locus theologicus played by the poor. This study constitutes the second of two articles devoted to the subject. Firstly, it delineates the journey, not lacking in opposition and ambiguity, that theology has carried out without which the magisterium could hardly have reached such conclusions. Then, it attempts to highlight the fundamental reasons that underlie the role of the theological place the poor play within theology, and proposes new research pathways in which the poor can help us to perform the three following tasks: to understand more appropriately the divine attribute of simplicity, to discover the direction history assumes because of its eschatological orientation, and finally to overcome those ecclesiologies that have allowed clericalism to progressively establish itself within the Christian community.
\end{abstract}

Keywords: The poor. Theological place. Option for the poor. Evangelii Gaudium. Liberation Theology. Clericalism.

Resumo: Existem razões sólidas para arguir que, com a Evangelii Gaudium, do Papa Francisco, o Magistério da Igreja Católica, finalmente, passou a reconhecer a função do locus theologicus exercido pelos pobres. Esse estudo é o segundo de dois artigos dedicados a esse tema. Primeiramente, busca-se reconstruir o caminho percorrido pela teologia, não isento de ambiguidades, sem o qual o Magistério dificilmente teria chegado a tais conclusões. Em seguida, procura-se destacar as razões fundamentais subjacentes ao papel do lugar teológico que os pobres exercem na teologia, propondo novos horizontes de pesquisa nos quais os pobres podem ajudar-nos a realizar as seguintes tarefas: entender mais adequadamente o atributo divino da simplicidade, descobrir a direção que a história toma em razão de sua orientação escatológica e, por fim, superar aquelas eclesiologias que permitiram que o clericalismo pudesse estabelecer-se no interior da comunidade cristã.

Palavras-chave: Os pobres. Lugar teológico. Opção pelos pobres. Evangelii Gaudium. Teologia da Libertação. Clericalismo.

\section{Introduction}

First of all, it is important to remember the path travelled by theology and its possible developments. The extraordinary pronouncements of Evangelii gaudium on the existence of a magisterium of the poor as active subjects in the church and protagonists of their journey of liberation, and therefore the implicit recognition of their being a theological locus, would not have been possible without the path taken by theology with the support of the whole ecclesial community, in a dialogue, not without 
misunderstandings, with the Congregation for the Doctrine of the Faith (CDF). Here, firstly, we sketch out the historical development of the important stages of this path. Secondly, on the basis of the acquisitions of theology and relying on the nexus mysteriorum, on the one hand we try to identify that fundamental theological framework within which the centrality of the poor in the Christian mystery acquires all its meaning, on the other we offer three new possible developments of some specific theological themes making use of the theological place of the poor. The article concludes with some considerations about the possibilities offered to the church by her renewed awareness of the mission entrusted by God to the poor in the history of salvation.

\section{The three stages of the development of Theology about the role of the poor in the life and reflection of the Church}

The path that led theology to the discovery and deepening of the poor as locus theologicus was far from being linear, in fact there were moments of euphoric discovery alternated with moments of arduous analysis. In this route we can identify three important stages. The first stage is that which leads to the affirmation of the theological place of the poor and the deepening of the meaning and the contribution it offers at the ecclesial and theological level. This stage also sees the rise of theologies from those Christian communities that open their doors to the world of the poor. The second stage is triggered by the CDF's interventions, which warn against the possible threats to the faith of the church represented by these 'new' theological positions without sufficiently appreciating their undeniable merits. The third stage is characterized by the debate generated by the magisterial interventions, which give rise to an important clarification thanks to the reflections of $E G$. We go through them, one after the other, without avoiding analysing in detail the thorniest issues that were raised throughout the journey.

\subsection{First stage: theology gradually rediscovers the centrality of the poor in the revelation of the God of Jesus Christ in history}

Theology receives the most important impulse to be interested in the poor by Vatican Council II (1962-1965). The Council paves the way for a reconsideration of the loci theologici through the retrieval of the evangelical category of the 'signs of the times' (cf. Unitatis Redintegratio 4, Dignitatis Humanae 15. Presbyterorum Ordinis 9. Gaudium et Spes 4), ${ }^{2}$ among which is the fact that 'a huge proportion of the world's citizens are still tormented by hunger and poverty, while countless numbers suffer from total illiteracy'(Gaudium et spes 4). ${ }^{3}$ In fact, immediately after the Council, there begins to appear a series of studies that aim at the possibility of elaborating a theology that starts 'from below', that is 'from the perspective of the outcast, the suspects, the maltreated, the powerless, the oppressed, the reviled-in short, from the perspective of those who suffer' (BONHOEFFER, 1971, p. 17). ${ }^{4}$ In 1971, Teologia de la liberación by $G$. Gutiérrez is published in Lima, where theology is presented as 'a critical reflection of historical praxis in the light of faith' (GUTIÉRREZ, 1972, p. 74); simply put, theology constitutes the 'second act', namely the critical reflection, which follows 'the first act', namely Christian life itself, whose solidarity and commitment to the poor constitute a fundamental

\footnotetext{
2 The category of the 'signs of the times' was used for the first time in the last century by John XXIII in the bull of induction of the Council Humanae Salutis of 25 December 1961, and subsequently in the scheme of Pacem in Terris. However, as early as 1937, Chenu had spoken of the different ways in which the church takes part in the great social movements of the time as 'active theological places' (CHENU, 1964, p. 259). 3 If in Gaudium et spes 4 the reference to the 'signs of the times' has a rather historical-pastoral significance, in Gaudium et spes 11 its significance is more historical-theological, since this number states that 'the People of God [...] labours to decipher authentic signs of God's presence and purpose in the happenings, needs and desires in which this People has a part along with other men of our age.' Contrary to what R. FISICHELLA holds (cf. Dizionario di Teologia Fondamentale, s.v. 'Segni dei tempi,' p. 1113), the signs of the times must not necessarily always express something positive, sometimes a greater understanding of the will of God and his action in a given historical moment stems from negative signs of the times. A peculiar characteristic of time is precisely its changeability (cf. Mt 16:2-3: //Lk 12:54-56). 4 Bonhoeffer expressed himself in this way probably already at the end of 1942. In the same years Emmanuel Mounier had said, 'Montreuil [that is the poor] is not infallible, but Montreuil is at the heart of the problem: we refuse the abstraction which omits the point of view of Montreuil,' (MOUNIER, 1963, p. 17).
} 
dimension (GUTIÉRREZ, 1972, p. 21).5 A year before, in 1970, in the Protestant circles, A Black theology of Liberation by J. Cone (1970, p. 63. 64) had been released, an expression of some voices of the African-American community, in which the blackness experience of oppression is in fact taken as a criterion of re-reading of the biblical revelation. ${ }^{6}$ In the immediately following years, there happens to be wider awareness, in the academic world, of the significance of this perspective for the whole of theology. In 1975. theologians gathered in the First Latin American Meeting of Theology in Mexico affirm that 'the real and effective option for the exploited [...] implies not only a new spiritual experience but also a new understanding of the faith.'7 In 1976, theologians gathered in Dar es Salaam for the First Meeting of the Ecumenical Association of Third World Theologians (EATWOT) come to affirm that the commitment to a form of life in solidarity with the poor and the oppressed' requires a real ' epistemological break' (LOIS, 1986, p. 56) in the very ways of doing theology. Finally, in 1979, in a collection of previously published essays, $L a$ fuerza historica de los pobres, while outlining the modern history of theology, especially the Latin American one starting 'from the reverse side of history'-that is showing how social, political and economic context seriously affects theology-G. Gutierrez explicitly states that the place of liberation theology [...] is found in the poor [...] in their presence as a creative and active subject of one's own history.' (GUTIÉRREZ, 1981, p. 245-246).

The 80 s and gos are the years in which this theological datum is deepened. In 1981, two important contributions are published: an article by I. Ellacuria, which specifically addresses the theme of the poor as a theological place (ELLACURIA, 1981, p. 225-240); also in (ELLACURIA, 1992, p. 135-153); and an essay by J. Sobrino, which has as subtitle 'the poor as the theological place

of ecclesiology' (SOBRINO, 1981). I. Ellacuria is concerned with defining three senses in which the poor constitute a theological place and the distinction between a theological place and the source of revelation. For Ellacuria the poor are a theological place for the following reasons: 'in that constitute the maximum and scandalous prophetic and apocalyptic presence of the Christian God' (ELLACURÍA, 1992, p. 142) among people, since the revelation of God in the New Testament is a kenotic revelation; because they offer 'the most suitable place to live our faith in Jesus and the corresponding praxis in order to follow him' (ELLACURIA, 1992, p. 144); and consequently because they represent the most appropriate place 'to reflect on faith, to do Christian theology' (ELLACURIA, 1992, p. 145). As for the distinction between a theological place and the source of revelation, he states that the source, or deposit, has the task of preserving the contents of faith, which are instead actualized and made present by the 'place'. 8

Therefore,

\begin{abstract}
in the light of this distinction, it would be erroneous to think that direct contact (though experienced in the believer's prayer) with the source may suffice in order to be able to perceive and infer what is most appropriate for constituting authentic theological reflection. The ultimate reason is that the Word of God, contained in the sources, is a referential and living Word, directed more to one than the other, understandable therefore, more to former than to latter. A Word, moreover, that is preserved and understood only through the action of the Spirit of Jesus, who is a spirit present in a preferential way in the poor (ELLACURIA, 1992, p. 146).
\end{abstract}

Consequently, the primary task of theology is not 'to clarify the mysteries in order to make them credible to the wise of this world,' nor to 'give reason for the hope or faith of Christians' but to 'help the needy in their active and passive practice for salvation' (ELLACURIA, 1992, p. 148); this is why, continues Ellacuria, even theologians, in carrying

\footnotetext{
5 ASSMANN, H. Teologia desde la praxis de la liberación goes in the same direction, especially replacing the expression 'Theology of liberation' with the expression 'Theology from liberation' (italics ours).

6 The author will better develop these insights later, in CONE, J. H. God of the Oppressed. New York: Seabury Press, 1975.

7 Intervention by Raúl Vidales reported by LOIS, J. Teologia de la liberación: opción por los pobres, p. 55.

8 However, for Ellacuria, 'The distinction is not rigorous and not even exclusive, since in a certain way a place is a source in that it allows the latter to give of itself this or that, so that, thanks to the place and by virtue of it, certain particular contents are actualized and become really present' (ELLACURIA, 1992, p. 145-146).
} 
out their mission, are subject to persecution, along with many simple Christians and pastors, 'by the powerful of this world and their allies, often even inside the church' (ELLACURIA, 1992, p. 148-149). The study by J. Sobrino, contrary to what one might believe, does not propose to rethink the treatise of ecclesiology starting from the perspective of the poor, but, much more appropriately, shows that the poor can be 'the authentic theological place of the understanding of Christian truth and praxis [...] those who pose to the church the fundamental theological problem and also the direction of its solution, only when the church concretely finds in them 'her principle of structuring, organization and mission (SOBRINO, 1981, p.109).9

In 1984, an article by J. I. Gonzalez Faus takes another step forward by beginning to reflect on the specific contributions that the theological place of the poor offers to the Christian faith, and identifies three of them. Firstly, to do theology by starting from the poor, helps, in his opinion, to get rid of the 'false theological places,' that is, of our defence mechanisms before God, since it allows us to be faithful to that orthopraxis which, according to the gospel of John, constitutes the true safeguard of orthodoxy. Secondly, it initiates to the mystery of the weakness of God (theologia crucis) for which the idolatrous image of God that the human being builds from the worldly glory (theologia gloriae) is replaced by the revelation of God as the 'Great Poor,'10 whose glory manifests itself in mercy towards the least. Thirdly, to do theology from the poor makes possible an 'embodied' understanding of justification by faith, since it sheds light on the experience of believers who, exactly by living among the poor, discover their poverty before God and his immense love (GONZALEZ FAUS, 1984, p. 275-308). In 1993, in Jesuscristo liberador, J. Sobrino offers a synthesis of the acquisitions reached by theology in almost
30 years of reflection on the poor (SOBRINO, 1995 , p. 45-68). The importance of this synthesis is, above all, due to the fact that he can take into account the progress made in the same years by the Latin American ecclesial communities who were guided by this perspective, generating 'a crowd of martyrs [...] killed like Jesus and for the same reasons that put Jesus to death' (SOBRINO, 1995, p. 57-58).

Basically, in this new study, Sobrino develops the acquisitions of the aforementioned article by Ellacuría. In fact, on the one hand, he is concerned with deepening the distinction between source and place, on the other, he still investigates what makes of the poor a theological place. In deepening the distinction between source and place, Sobrino makes use of the classical distinction between content of faith (fides quae) and act of believing (fides qua), which is actualised in the real following of Christ. He declares that if the sources of revelation (the Holy Scripture and Tradition) provide the content of the faith, a theological place constitutes the place where the believer lives his or her faith, that is, the place where the meeting with the living Christ becomes possible in history. From this, in his opinion, it is easy to understand how source and place are interrelated and how the hermeneutic circle enters into action between them. Sobrino affirms that Christian revelation, in the world of the Latin America poor, has guaranteed a special experience of God to ecclesial communities, and this same experience has in turn cast a greater light on the contents of revelation, once again bringing attention to the world of the poor (SOBRINO, 1995, p. 54). For these reasons, according to the author, 'the world of the poor'(SOBRINO, 1995. p. 54) is above all a theologal place, that is the vital place, the Sitz im Leben, where God himself is met, and then also a theological place, that is a place where it is possible to better think

\footnotetext{
9 SOBRINO quotes ELLACURIA, I. La iglesia de los pobres, sacramento histórico de liberación, p. 717.

10 In 1963 Maurice Zundel had already said, 'God is the greatest poor [...] which highlights the huge difference between the common notion of divinity [on the one sidel [...] of all believers who say they are such and see in God the great owner, the great rich who can do anything, who cannot expect anything so much he is very assured of his riches, who dominates us with all his power, who lets parsimoniously fall the crumbs of his table for us and asks us a fierce account of the use we make of it, and the true God lon the other side], the Christian God, the God who reveals himself in Jesus Christ. He is a God who has lost everything eternally, so he cannot lose anything! He has given everything eternally, and he cannot give more because this gift constitutes Himself in his personalism based solely on charity' (ZUNDEL, M. Émerveillement et pauvreté, p. 44-45)
} 
about faith. As for the reasons that justify the theological place of the poor. Sobrino argues that it is necessary to consider it from two points of view, corresponding to its main ways of making itself accessible in reality, namely, as ecclesial place and social-theologal place. He affirms that the theological place of the poor as an ecclesial place-that is, constituted by a church that really makes of the poor 'her main subject and her principle of internal structuring'(SOBRINO, 1995. p. 57$)^{11}$ - offers three opportunities: the possibility of following the liberating practice of Christ; the possibility of understanding revelation by starting from the faith of the poor, its privileged recipients; and the possibility of a special encounter with the Crucified-Risen in history, since the poor place their hope, their liberating practice and their suffering at the service of his ecclesial body. On the other hand, when considered as a socialtheological place, in his opinion, the theological place of the poor acts in three specific ways: it provides a reality, that of the immense suffering of humanity, which poses very concrete questions to theology; it offers a clearer view of the deposit of faith as evidenced by the centrality given to the cross in Christian biblical theology; and it immunises against that hubris, inevitably at work in all that is human, capable of transforming theology into ideology. As it can be deduced from this description, for Sobrino, the theological place of the poor, 'as an ecclesial place, above all influences [theologicall content,' whereas as 'a social place, it above all influences [theological] thinking' (SOBRINO, 1995, p. 559-60). In 1998 with Los pobres y la teologia, J. M. Castillo continues to explore, in the wake of J. I. Gonzales Faus, what is specifically revealed by the theological place of the poor. By starting from the gospels, which testify that 'Jesus' fundamental concern is not sin but human suffering'(CASTILLO, 2002, p. 12), the author points out that the choice of God to share human weakness, in all its forms, manifests that God 'is not defined or understood as starting from power, but [...] from love.' (CASTILLO, 2002, p. 117)
From this springs that 'the centre of Christianity is life, because first of all love is life' (CASTILLO, 2002, p. 190-191) and that by virtue of this love the Christian should live in freedom from law and religion, when they are perverted by human pride, which pushes Christians to withdraw into themselves and search for self-sufficiency.

Even if outside the American continent, in the same years, there is no explicit reflection on the poor as a theological place, in Asia and Africa there are theologies that deal with the poor as a real theological place, also because they are generated from ecclesial communities that really welcome the poor in their womb.

As far as Asia is concerned (ROWLAND, 2007, p. 55-78), in the 70s, Suh Nam-Dong, Kim YongBock and Ahn Byung-Mu (FERM, 2004, p. 97-98) originate, in South Korea, the Minjung theology, which takes on the pain of the oppressed people. In the 80s, in India, the Dalit theology appears, which is elaborated starting from the excluded from the caste system; among its authors of greatest importance we can mention Arvind P. Nirmal (NIRMAL, 1989). At any rate, theologians who take seriously the reality of the poor are also Kosuke Koyama, in Japan, (NIRMAL, 1989, p.7880), Choan-Seng Song, in Taiwan (NIRMAL, 1989, p. 83-84), Sebastian Kappen and Samuel Rayan, in India (NIRMAL, 1989, p. 91-92; ROWLAND, 2007, p.68-69)), Tissa Balasuriya and Aloysius Pieris in Sri Lanka (FERM, 2004, p. 84-87), Carlos $\mathrm{H}$. Abesamis in the Philippines( FERM, 2004, p. 88-89). These Asian theologians are distinguished from their colleagues of America because they write in a context in which 'the overwhelming majority of the poor and oppressed [...] are nonChristians, many of which adhere to a wide variety of popular religious traditions which are more or less connected with the traditions of the great religions which have shaped dominant Asian cultures' (ROWLAND, 2007, p. 55).

In Africa, the need for a contextualized theology had been present since 1956 with the publication of Des prêtres noirs s'interrogent (ABBLE et al),

${ }_{11}$ Following ELLACURIA, I. Conversione della Chiesa al Regno di Dio, p. 175. 
while a theological thought able to seriously take into account the condition of the overwhelming majority of the population in 'the fatherland of the poor, the weak, and the oppressed'12 arises in many parts since the beginning of the 80s. Among the most significant expressions of this thought we have the works of J. M. Ela, E. Mveng, and The Kairos Document published in 1985 in South Africa. ${ }^{13}$ Ela promotes a 'shade-tree theology', a theology of solidarity that 'far from the libraries and the offices, develops among brothers and sisters searching shoulder to shoulder with unlettered peasants for the sense of the word of God in situation in which this word touches them.' ${ }^{14}$ Mveng does theology by starting from the discovery of the 'anthropological poverty, ${ }^{15}$ which characterizes the African continent, and which constitutes a real process of 'depersonalization and anthropological annihilation.'16 The Kairos Document-a true testimony of theology as 'second act', since it was signed by 151 Christians of different denominations (pastors, priests and lay people) engaged in various movements against the apartheid-criticizes the 'state theology', which misuses 'theological concepts and biblical texts for its own political purposes,' and the 'church theology', which 'relies upon a few stock ideas derived from Christian tradition and then uncritically and repeatedly applies them to our situation,' and inclines to a 'prophetic theology' capable 'of engaging in an in-depth analysis of the signs of our times' while serving a church that 'as a whole' takes sides with the poor and the oppressed (THE KAIROS DOCUMENT, 1985).

\subsection{Second stage: the prudential warnings of the magisterium}

The discovery and deepening of the importance of the poor for the church and theology catch 'Rome' unprepared, and the Congregation for the Doctrine of the Faith (CDF) prefers to focus its attention on the possible threats that these 'new' acquisitions may constitute for ecclesial life and truths of faith. This attitude of the CDF remains unchanged for more than twenty years, given that it first appears in an articulate way in 1984 with the publication of the instruction Libertatis Nuntius $(L N)$-to read together with Libertatis Conscientia (LC) of 1986-and is reconfirmed in 2006, when two joint documents, the Notification on the works of the Father J. Sobrino (NWJS) and its Explanatory Note (ENo), are made public. ${ }^{17}$ We start carefully examining what is relevant for our topic in $L N$ and then concentrate on the documents related to the works of J. Sobrino.

\section{LN: a missed opportunity}

The Instruction on Certain Aspects of the Theology of Liberation, that is $L N$, warns, in a somewhat one-sided way, against three risks to which certain options highlighted by the Latin American reflection on the poor would lead, ignoring two fundamental questions for the church and theology that this same reflection raises. We

\footnotetext{
12 E. Mveng at the opening of the first colloquium of African and European theologians at Dar es Saalam in 1976, reported by ÉLA, J.-M. My Faith as an African, p. 125.

${ }_{13}$ Cf. GHIBELLINI, R. La teologia del XX secolo, p. 500-510. South African theology begins to take seriously into consideration the conditions of the oppressed under the stimulus of the United States Black Theology. Important moments of this development are the following: the conferences of the University Christian Movement in 1971 and the essay by BUTHELEZI, M. An African Theology or a Black Theology, both of them in MOORE, B. (Ed.). Black Theology: The South African Voice; Desmond Tutu's conferences of 1973, then published in the volume TUTU, D. J'ai aussi le droit d'exister; and the contribution of BOESAK, A. A. Farewell to Innocence.

14 ÉLA, J.-M. Cri de l'homme Africain, p. 8.

15 During the fifth meeting of third world theologians, at New Delhi in August 1981, African theologians launched the concept of 'anthropological poverty.' cf. METOGO, É. M. Dieu peut-il mourir en Afrique?, p. 180. Mveng develops this concept in MVENG, E. L'Afrique dans l'église: paroles d'un croyant, p. 199-213.

${ }_{16}$ Thus he describes this process: 'When persons are deprived not only of goods and possessions of material, spiritual, moral, intellectual, cultural, or sociological order, but of everything that makes up the foundation of their being-in-the-world and the specificity of their 'ipseity' as individual, society, and history-when persons are bereft of their identity, their dignity, their freedom, their thought, their history, their language, their faith universe, and their basic creativity, deprived of all their rights, their hopes, their ambitions (that is when they are robbed of their own ways of living and existing)-they sink into a kind of poverty which no longer concerns only exterior or interior goods or possessions but strikes at the very being, essence, and dignity of the human person. It is this poverty that we call anthropological poverty. This is an indigence of being, the legacy of centuries of slavery and colonization' (MVENG, E. Impoverishment and Liberation, p. 156). 17 Although these documents are accessible in their English translation on the official website of the Holy See (http://w2.vatican.va/ content/vatican/en.html), for their correct interpretation it is better to go to the Spanish texts, since this translation does not seem to be reliable ('lugar teológico fundamental' is translated into 'the fundamental position,' 'cualquier otro lugar teológico' is translated into 'all other theological foundations,' and 'lugar ecclesial' is translated into 'ecclesial foundation').
} 
analyse the warnings of the congregation against these three risks together to their one-sidedness; afterwards, we focus on the two evaded questions.

Firstly, in the primacy given to orthopraxis the congregation sees the danger of assuming, through Marx, the Hegelian principle according to which history itself determines the truth ( $L N$ IX,3-6.8; X,3) and not faith ( $L N V I I, 10)$. However, in doing so, it overlooks the fact that, for the Holy Scripture, it is the ethical dimension of faith that decides the value of its noetic dimension, and not vice versa. ${ }^{18}$

Secondly, in choosing to follow Christ through sharing one's life with the poor, and the commitment to the liberation of the oppressed, the congregation sees the danger of both the assumption of the Marxist principle ${ }^{19}$ of the class struggle (LNVIII, 7; IX, 3.7.10; X, 9.10) as the ultimate criterion of analysis of reality $(L N X, 2)$, and the choice of violence in order to bring about social justice. This would be contrary to Christianity according to which the true triumphant force is the gift of the love of God ( $L N X, 16)$, which socially turns into universal love ( $L N I X, 2)$ and produces its fruits through 'the non-violent means of dialogue and persuasion' ( $L N \mid X, 7)$. However, it must be said that the class struggle is not an invention of Marx, rather it represents an undeniable social fact. ${ }^{20}$ Actually, Marx should be credited with having identified the primary subject of historical liberation of peoples with the oppressed;21 and this is so because, as G. Girardi says, 'the oppressed are interested in unmasking reality [...] the oppressed need light more than all; more than everyone, they are ready to welcome it.'22 The CDF is quite right to point out that $\sin$ is 'the source of all evils' (LNX, 7), thereby warning us against a unilateral understanding of reality, which could lead to trace everything back to social conflict. Yet it would be really misleading to think that universal Christian love expresses itself only through the non-violent means of dialogue and persuasion. If Jesus' non-violence were limited to this, he would never have been crucified. Since in the mystery of Christ the very love of God has really entered into the present aeon, it is truly impossible that it does not radically come into conflict with the sinfulness of this world, because of its resistance to letting itself be transformed eschatologically. ${ }^{23}$ The gospels

\footnotetext{
18 In the Scripture we do not find the expression 'if I have all love but have not faith, I am nothing,' but 'if I have all faith [...] but have not love, I am nothing' (1Cor 13:2), together with a whole series of texts that support the primacy of evangelical praxis on the simply verbal confession of faith and, in a certain sense, the sacramental practice itself (cf. Mt 7:15-27; 12:33-35; //Lk 6:43-49; Mt 25:31-46; Lk 10:29-37; 13:25-27; Rm 2:13; Ga 5:6; Jm 2,14-26; 1Jn 3:18).

19 According to $L N$ VII,6, 'the thought of Marx is such a global vision of reality that [...] no separation of the parts of this epistemologically unique complex is possible. If one tries to take only one part, say, the analysis, one ends up having to accept the entire ideology.' Strangely enough, the attitude of the congregation towards Greek culture in NWJS 3. when it must defend Christianity against the accusations of Hellenization, is diametrically opposed: 'If these Councils used the terminology and concepts expressive of the culture of the time, it was not in order to be conformed to it. The Councils do not signify a Hellenization of Christianity but rather the contrary. Through the inculturation of the Christian message, Greek culture itself underwent a transformation.' Subsequently, Cardinal G. L. Müller, during his mandate as prefect of the Congregation for the Doctrine of the Faith, will be able to write, 'the validity of specific sociological and economic insights into the system of modern industrial institutions, as these insights are brought to expression by Marx, has not expired. Moreover, these insights are not inseparable from Marxism's atheistic view of human beings,' (GUTIÉRREZ; MÜLLER, 2015, chap. 4).

20 Cf. Quadragesimo anno 82/83: 'human society now, for the reason that it is founded on classes with divergent aims and hence opposed to one another and therefore inclined to enmity and strife, continues to be in a violent condition and is unstable and uncertain.' Today, we must unfortunately acknowledge what the title of a recent publication, which debunks the dogmas of neoliberal policies, notes: 'class struggle exists and the rich have won it' (cf. REVELLI, 2014).

${ }_{21}$ However, there is a fundamental difference between Marxist and Christian perspectives. 'For Marx and Engels truth about history lies in the point of view of the winning social group, they do not take sides with the poorest and the weakest' (ELLACURIA, 1992, p. 44-45), so much so that those who are the last of the social ladder, Lumpenproletariat, the underclass devoid of class consciousness, has no social transformational function in their opinion. On the other hand, as noted by GIRARDI, G. La tunica lacerata, p. 243-245, 'the choice of Christians is not motivated by the fact that the popular classes are strong and are, in prospect, winning, but by the fact that they are weak,' for, we could add, Christian 'power is perfected in weakness' (2Co 12:9).

22 GIRARDI, G. La tunica lacerata, p. 247. In the same direction ELLACURIA, I. Conversione della Chiesa al Regno di Dio, p. 100-101. Girardi, however, specifies that 'to affirm the connaturality of the poor with the truth is not possible except in the light of a conception of the truth that is [...] transforming; a truth that is not only defined in relation to what exists, but also to what can and must exist' (GIRARDI, 1986 , p. 248). The poor are the ones who open the horizon of God, they are the hope of the world. Those who have their permanent city here don't hopes for a future one.

${ }_{23}$ When Cardinal Müller becomes head of the Congregation of the doctrine of Faith, after Cardinal Ratzinger, under whose direction the documents of the congregation we are analysing were issued, he shows to share what we have just noticed; in fact, he points out that 'Christian faith surely does not hold a notion of history as a simply harmonious, ever-evolving reality. It perceives grace and sin at work in the antagonistic, moving interaction in the historical drama. According to liberation theology, grace and sin find a form of expression today in the social opposition between oppression and freedom' (GUTIÉRREZ; MÜLLER, 2015, chap. 4).
} 
present to us a Jesus who explicitly distances himself from conciliatory positions (cf. Mt 10:34; //Lk 12:51; Jn 14:27; 16:33), whose 'nonviolence' manifests itself as a force that, even if it is unable to harm in any way, it does not hold back, up to the frontal collision with the religious, political, social and economic manifestations of sin.

Thirdly, in the desire to seriously give a voice to the poor in the church, ${ }^{24}$ the Congregation sees the danger of understanding the church of the poor as a class church engaged in the revolutionary struggle ( $L N I X, 10 ; X, 1.15)$, in which the relationship of the hierarchy with the basis is realised in terms of domination $(L N I X, 2 ; X, 1)$ and the sacramental origin of ecclesial ministries is questioned $(L N I X, 13 ; X, 15)$. For the CDF, an operation of this type tends to consider the church 'a reality interior to history, herself subject to those laws which are supposed to govern the development of history in its immanence' ( $L N$ IX,8), while she constitutes 'a spiritual reality which cannot be reduced to a purely sociological analysis' ( $L N X, 15)$. However, it must be said that statements of this type run the risk of supporting a monophysite conception of the 'church of the Incarnation' (LNXI, 5) designed to immunize the service of the magisterium against any criticism, of which we know at least that 'is not above the word of God' (Dei Verbum 10). ${ }^{25}$ In reality, the church, 'one complex reality which coalesces from a divine and a human element' (Lumen gentium 8), must also be analysed as a really, though not exclusively, human phenomenon, just as Christ is and even more than him, since her human element unlike
Christ is not exempt from $\sin .^{26}$

By warning against the risks of politicization of the faith (cf. $L N \mid X, 6$ ), to which the 'new hermeneutics' proposed by the Latin American theology might lead ( $L N X, 5-7.12 .16 ; \mathrm{XI}, 17$ ), the CDF provides without doubt a useful service to the theological development that is put under judgment, but we must add that it fails to understand precisely what its merits are, which go well beyond having restored 'to a place of honour the great texts of the prophets and of the gospel in defence of the poor' ( $L N I X, 10)$. In fact, the congregation does not answer the two fundamental issues that this theology puts to the attention of the church. In the first place, by simply reaffirming 'the practical orientation' of theology ( $L N X, 3$; cf. $X I, 13$ ) or by consenting to the fact that 'a theological reflection developed from a particular experience can constitute a very positive contribution,' especially the experience that 'shines [...] in the lives of the saints' (LC 70), the CDF does not yet pronounce on the epistemological question about the constant influence that a given ecclesial practice in a given vital context exerts on theological doing, or, looking a little further, it does not yet pronounce on the relationship between charity and theology, ${ }^{27}$ between the church's attribute of the 'indefectible holiness' (Lumen gentium 39) and the charisma of inerrancy with which she was endowed (Lumen gentium 12; 25) 28 The Johannine literature seems to go decisively in this direction when it relates 'love' and 'light' (cf. Jn 3,19; 20,8; 1Jn 1,6; 2,9-11). In the second place, considering the poor only

\footnotetext{
24 CASTILLO, J. M. I poveri e la teologia, p. 30 points out that vímıo, used in Mt 11:25, literally means 'those who have no word,' in Latin we would say infantes.

25 The difficulty of making this theological datum fruitful has been expressed by Christopher Butler, a peritus at the Council in WITHERUP, R. D. Scripture: Dei Verbum, p. 99: 'It is all very well for us to say and believe that the magisterium is subject to Holy Scripture. But is there anybody who is in a position to tell the magisterium: look, you are not practicing your subjection to Scripture in your teaching?' The question is also raised by VERWEYEN, H. La parola definitiva di Dio, p. 457.

${ }_{26}$ The 1981 essay by Leonardo Boff (Igreja charisma and poder) goes in this direction. The CDF, which just a year before had produced $L N$, was not in the best condition to appreciate the positive contributions of the work of L. Boff, so with a notification (CDF. Notification on the book 'Church: Charism and Power' by Father Leonardo Boff OFM, 1985) it limits itself to warning against the danger of sustaining a relativizing concept of the structure of church, of analysing sacred power as a merely sociological fact, and of misunderstanding that the exercise of prophetic role is subject to hierarchy (cf. Lumen gentium 12). It must be said that these warnings retain their legitimacy only insofar as they do not exclude that even the church 'in her sacraments and institutions, has the appearance of this world which is passing' (Lumen gentium 48), and that uncontrolled exercise of sacred power is unlikely to be free of abuse (as the paedophilia scandal erupted in this century has brought to light) thereby turning church's prophecy into a sort of posthumous rehabilitation of the prophets (cf. Mt 23:29-31). ${ }_{27}$ Pope Francis addresses the topic in Veritatis Gaudium 4 by quoting Antonio Rosmini: 'In the unity of science and holiness "we find the true spirit of that doctrine which is destined to save the world".'

${ }_{28}$ Catechism of The Catholic Church (CCC) 869 connects infallibility to apostolicity; instead, Siegfried Wiedenhofer, in his ecclesiology, connects inerrancy/infallibility to sanctity on the basis of Mt 16:18; 28:20 and Jn 16:13 (cf. WIEDENHOFER, S. Ecclesiologia, p. 143. In any case, CCC 811 states that the four marks of the church are 'inseparably linked with each other.'
} 
as passive objects of the church's care (cf. $L N$ IX, 9.11, XI, 2.18, Conclusion), the CDF seems to overlook the ecclesiological question about the possibility of seeing in the fundamental option for the poor an indication regarding not only the church's mission but more properly her structure. ${ }^{29}$

\section{NWJS: the real, crucial issue comes out}

Twenty years later, the CDF intervenes again on these topics by issuing a notification, with an explanatory note, on the two Christology volumes by Sobrino, one published in 1991 and the other in 1996. This time, given the changed international political climate that sees the dissolution of the Soviet bloc and, with it, of the fascination for dialectical materialism, the congregation dwells precisely on the epistemological and ecclesiological aspects that the choice to place the poor at the centre of ecclesial life, and to do theology for them and with them entail. However, even after this long period of time, it remains entrenched in a position similar to that assumed in LN. The CDF warns against Sobrino's theological epistemology, since the author in question considers 'the church of the poor' as 'the fundamental theological place' (NWJS 2), 'the ecclesial place' (ENo 3; cf NWJS 2), or 'the point of departure' (cf. NWJS 2) and the 'matrix' (NWJS 11) for theological work, instead of 'the faith of the church,' also called the 'ecclesial faith' or 'the apostolic faith transmitted through the church' (NWJS 2). The CDF does not exclude the existence of 'other theological places' but these 'find their correct epistemological setting' in 'this ecclesial faith' (NWJS 2). The problem is to understand what the CDF intends exactly for 'ecclesial faith'. It does not seem that the congregation refers exclusively to the texts of the Holy Scripture and to other types of documents inherited from Tradition, it seems rather it refers to the reality of the whole church as a 'transtemporal subject of the faith' (NWJS 3), since it states that 'the purpose of this Notification is precisely to make known to all the faithful the fruitfulness of theological reflection that does not fear being developed from within the living stream of ecclesial Tradition' (NWJS 11), where by Tradition it is clearly meant a 'living' reality (cf. Dei Verbum 8). Be that as it may, the church as 'transtemporal subject of the faith' should not be thought of as a subject that exists 'beyond time' but 'through time', for she walks not by sight but by faith (2Co 5:7), therefore there should be no reason to counterpose her against the 'church of the poor', which Sobrino and Ellacuria understand as the place where the following of Christ, 'the incorporation of Jesus Christ in the reality of history' (ELLACURÍA, 1992, p. 157), is performed. To understand the reasons for this unjustified opposition between the 'church of the poor' and the Catholic church, it is useful to examine an interview released, at the time of the two instructions on Liberation Theology, by the then prefect of the CDF, J. Razinger, where those that appear to be two opposite ways of being church in the notification on Sobrino are counterposed in very similar terms right within the discussion about the interpreting subject of the Holy Scripture:
As far as the arbiters are concerned, the crucial concepts are people, community, experience and history. Previously it was the church, na- mely, the Catholic church in her totality - a totality which spanned time and space and embraced laity (sensus fidei) and hierarchy (magisterium) - that constituted the herme- neutical criterion; now it is the 'community'. The experience of the 'community' determines the understanding and the interpretation of the Scripture [...] the gospels' picture of Jesus is itself a synthesis of event and interpreta- tion, based on the experience of the individual communities [...] the community 'interprets' the events on the basis of its 'experience' and thus discovers what its 'praxis' should be. The same idea appears in a somewhat modified form in connection with the concept of [...] 'the People of God'... The experiences of the 'people' elucidate the Scripture [...]. Finally, the concept 'history' becomes a crucial interpretative cate- gory [...] history is the real revelation and hence the real interpreter of the Bible. (RATZINGER; MESSORI, 1985, p. 181-182)

29 For example, Pope Francis goes so far as to sketch 'the image of a synodal church as 'an inverted pyramid' which comprises the People of God and the College of Bishops, one of whose members, the Successor of Peter, has a specific ministry of unity. Here the summit is below the base;' in International Theological Commission Synodality in the Life and Mission of the Church, p. 57. 
The reason why Ratzinger distances himself from a Christian community, or the People of God, who interprets the text of the Holy Scripture in its historical context in the light of the experience made by historically realizing the praxis of Jesus, is the fear that to accept this hermeneutical circle means to open the doors to anti-metaphysical relativism, ${ }^{30}$ which would make superfluous 'a teaching office which insists on abiding truths. ${ }^{31}$ We can therefore reasonably think that the notification of the CDF sees in the proposal to integrate into the theological method the requests coming from a hermeneutics that takes seriously the context in which theology is done, a danger for the truths of faith, still conceived in a way that is too 'essentialist'. 32 The CDF, thus, seems to place the church, as a believing and interpreting subject, in a temporal dimension that keeps it sheltered from the contingency of the world and, in this specific case, from the poor. ${ }^{33}$ This, however, leads, once again, to an insufficient way of thinking of the church in analogy to the mystery of the incarnate Word (cf. Lumen gentium 8) and, in this case, to a kind of ecclesiological Docetism for which one wants that the church, in an attempt not to be 'of this world,' tries to be as little as possible 'in this world' (cf. Jn 17:14-18). As a consequence, one carves out for the church a solitary space of superiority with respect to the world, which makes her yield to a form of worldliness subtler than that which one wishes to avoid. ${ }^{34}$ Hence the risk, expressed by Ivone Gebara in a biblical language, of building 'religious empires' that end up by preaching and demanding a theology of the Tower of Babel:

\begin{abstract}
They construct towers and, from on high, supervise the actions and thoughts of the workers, demanding that they speak the same language... They act as if they needed to defend the orthodoxy and purity of Christ, protecting Him from beggars, prostitutes, widows, strangers, farmers, critical thinkers who sit at the same table [...]. They forget, perhaps, that the greatness of Christianity began in a manger, in the welcoming of a child, born of a woman in the dark night of an exploited people. (VIGIL, 2007, p. 143)
\end{abstract}

\subsection{The third stage: the reactions of theology between rethinking and deepening until the synthesis attempt provided by Evangelii Gaudium}

The succession of the CDF's interventions opens a debate in which the theologians who have reflected on the poor as a theological place take very different positions. The most structured are those of G. Gutiérrez, C. Boff (the brother of the more famous L. Boff), and J. Sobrino. A decisive word on the issue comes, in the end, right from Evangelii gaudium thanks to its choice of starting from concerns different from those that had inspired the previous documents of the CDF.

Taking note of Rome's criticisms, G. Gutierrez chooses rather to reassure the congregation than to deepen the thorny issues. ${ }^{35} \mathrm{He}$ confines himself to saying that the greatest contribution given by liberation theology to the universal church is in reality the preferential option for

\footnotetext{
30 For Ratzinger this hermeneutical process leads to interpretations that 'can be dissolved and reformed continually' (RATZINGER: MESSORI, 1985, p. 181).

31 RATZINGER, J.; MESSORI, V. The Ratzinger Report, p. 182. Two times, in his reflection, Ratzinger attributes to liberation theologians the idea that 'thinking metaphysically' is not biblical and therefore not even Christian.

${ }_{32}$ In his reflections on NWJS and its way of considering the hermeneutical method, Alberto Parra sheds light on the implications of an essentialist theology: 'For an essentialist theology indeed the order of methodic grading starts from the text as a normative place, passes (if it passes) through the contextual ecclesial place, and generally lacks of pretextual place of applicability, of validity and of facticity in order that the text should produce its redeeming effects in the real misery of existence. This method starts from the answer and it is built without any question' (VIGIL, 2007, p. 191).

33 En 1 continues to look to the poor in a welfare manner without considering them an ecclesial subject in every aspect.

34 In Elenco di proposizioni erronee e pericolose found in the works of Sobrino, unpublished and quoted by COSTADOAT, J. El lugar en Jon Sobrino, 26, the CDF asserts that 'the church [...] in her faith is the humble people of God, the people of the 'poor in the Spirit." If this statement was read, for example, in the slums of Nairobi where people struggle daily for their survival, it would sound rather rhetorical and even offensive. This can give an idea of how certain pronouncements can be proposed from places that appear to be outside the world where the majority of people live.

35 This attitude was already pointed out to him in 1985, during the discussion of his thesis (cf. GUTIÉRREZ, 1990, p. 50-51) and the author himself confirms it (cf. GUTIÉRREZ, 1990, p. 59). It is also observed in Dizionario dei teologi, s.v. 'Gustavo Gutiérrez,' p. 298.
} 
the poor, ${ }^{36}$ which in any case should not be idealized (Cf. GUTIÉRREZ; MÜLLER, 2015, chap 5). This preferential option has a theocentric (Cf. GUTIÉRREZ, 1990, p. 24-25; GUTIÉRREZ; MÜLLER, 2015. chap. 5.), rather than political, motivation, since it finds its foundation in the gratuitous love of God.37 'The great hermeneutical principle of faith' (GUTIÉRREZ, 1990, p. 15) is basically Christ himself-as the incarnate Son of God, he does not exclude but makes possible the 'fundamental hermeneutical circle: from the human being to God and from God to the human being, from history to faith and from faith to history.' ${ }^{38}$ When he has to explain the importance of the theme of the 'church of the poor' in Latin American theology, he just points out that, with it, Latin-American theologians do not want so much to accentuate the social aspects of the church's mission as to highlight her being 'a sign of the Kingdom of God' (GUTIÉRREZ, 1990, p. 232). On the other hand, to define the meaning of doing theology starting from the poor, he contents himself with referring to a theology that starts from 'a particular experience' ( $L C$ 70) or from pastoral experience among the poor (cf. $L N X I, 13$ ), thereby welcoming the only two interpretations of the assumption of the poor as a theological place that the two instructions of the congregation consider legitimate. ${ }^{39}$

C. Boff goes dangerously beyond the equilibrium reached by Gutierrez. In a 2008 article, he does not limit himself only to highlighting the risk, always possible, for theology to idolize the poor, but goes so far as to claim that the poor cannot be 'the great theological place to know God or Christ' (BOFF, 2008, p. 4) because the privileged place to know God can only be the incarnate Word (Cf. BOFF, 2008, p. 3). Consequently, when he examines the role played by the historical context in doing theology, although he refers to Fides et Ratio 95. where there is room for the 'use of hermeneutic open to the appeal of metaphysics,' he argues that 'the contextual aspect of theology concerns only the 'body' of the text, not its 'soul', that is its meaning or its intentional purpose,' and that 'to insist that faith always occurs in a context (which is only a quarter of truth) without perceiving it in its transcontextual essence (which is already the three quarters of truth) cannot justify its transcendence' (BOFF, 2008, p. 14). If NWJS limited itself to talking about the transtemporal subject of faith, C. Boff goes so far as to speak about the transcontextual object of faith, and in fact ends up attributing to Christ, on epistemological level, that absolute primacy that he possesses on an ontological level-indeed the first Adam does not play a merely accessory role for the understanding of the last Adam (cf. 1Co 15:45), but he remains, so to speak, his 'grammar' forever. Now we must say that the poor, in a certain sense, provides many Latin American theologians with nothing but the best 'grammar' to understand the humanity taken on by Christ, which has been a

\footnotetext{
Cf. GUTIÉRREZ, G.; MÜLLER, L. On the Side of the Poor, chap. 3 and 5. VIGIL, J. M. La opción por los pobres es opción por la justicia, y no es preferencial, p. 153 relativizes the importance assumed by the preferential option for the poor in the church's magisterium: according to Vigil, being an option for justice, the option for the poor cannot be just preferential.

37 Cf. GUTIÉRREZ, G.; MÜLLER, L. On the Side of the Poor, chap. 3 and 5. The insistent emphasis on the gratuitous love of God as the ultimate root of the preferential option for the poor leads Gutierrez to underestimate the importance of human compassion and almost to forget that it is necessary 'to love man, we say, not as a means but as the first goal, toward the final and transcendent goal which is the basis and cause of every love' (Address of Pope Paul VI during the last general meeting of the Second Vatican Council, 7 December 1965). A more radical critique comes from VIGIL, J. M. La opción por los pobres es opción por la justicia, y no es preferencial, p. 156; for Vigil, when one seeks to find in God the origin of the option for the poor, one should refer to his love and his justice simulatively (cf. 1Jn 3:10), and not simply to his gratuitous love, as if it was only a question of an excess of divine tenderness. In this regard it may be useful to report a clarification of Ellacuria: 'Neither justice precedes love, nor love is the fulfilment of justice. Justice represents the historical form of objectified love,' (ELLACURIA et al., 1980, p. 21).

38 GUTIÉRREZ, G. La verità vi fará liberi, p. 142 quoting GUTIÉRREZ, G. La forza storica dei poveri, p. 76. However, in another essay published within this same book the author states that it is not a question of 'starting from the man to go to God (as when we talk about Christology from below), but starting from the universe of oppression and aspiration to liberation, in which the poor live' (GUTIÉRREZ. 1981, p. 287). The reality is that the language of Gutierrez has now become more sapiential, moving away from the 'eschatological' tone used in GUTIÉRREZ, G. La forza storica dei poveri, p. 262, which, for example, urged not to produce a theology that demobilized the commitment of the poor in their journey of liberation.

39 Cf. GUTIÉRREZ, G. La verità vi fará liberi, p. 72 and 138-140. Gutiérrez refers to the understanding of the spiritual experience as a theological place proposed in RATZINGER, J. Luther et l'unité de l'Église, p. 126
} 
'contextualised' humanity. ${ }^{40}$

For his part, not having found relevant the accusations made by the CDF, J. Sobrino develops further his reflections, and thinks of doing theology from the poor as a mystagogy, which, starting from the mystery of the poor, introduces better into the mystery of God and vice versa (Cf. VIGIL, 2007, p. 307). His essay No Salvation outside the Poor (SOBRINO, 2008), which explores the soteriological mission of the poor, moves in this direction. For the author, although the mysterium iniquitatis (Cf. SOBRINO, 2008, p. 49) is in operation even in the world of the poor, they offer an indispensable contribution to the humanization of a world 'dehumanized by our selfishness and by our insensitivity' (SOBRINO, 2008, p. 41), since 'the innocent victims save precisely by moving us to conversion, to being honest with reality, to having hope, to practicing solidarity' (SOBRINO, 2008, p. 66).

$E G$, finally, relaunches the debate in a more promising way. While highlighting a completely different series of dangers for the life of the church and the theology, which CDF could not perceive, the apostolic exhortation brings a greater balance in the teaching of the magisterium. What is important for Pope Francis is 'to listen to what God's word teaches us about mercy,'41 more specifically, to 'incarnate the duty of hearing the cry of the poor', being 'deeply moved by the suffering of others' (Evangelii gaudium 193). 'No ecclesial interpretation has the right to relativize' this message; in fact, 'we should not be concerned simply about falling into doctrinal error, but about remaining faithful to this light-filled path of life and wisdom' (Evangelii gaudium 194). For the Pope, to renounce 'the realism of the social aspect of the gospel' entails a very serious danger, that is to say, to rely on 'purely spiritual Christ, without flesh and without the cross' (Evangelii gaudium 88). The exhortation warns also against different kinds of people: those who 'observe certain rules or remain intransigently faithful to a particular Catholic style from the past' (Evangelii gaudium 94); those who show 'an ostentatious preoccupation for the liturgy, for doctrine and for the church's prestige, but without any concern that the gospel have a real impact on God's faithful people and the concrete needs of the present time' (Evangelii gaudium 95); those who have 'an obsession with programs of self-help and selfrealization' (Evangelii gaudium 95); those who 'look on from above and afar [...] reject the prophecy of their brothers and sisters [...] discredit those who raise questions [...] [and] constantly point out the mistakes of others' (Evangelii gaudium 97). Following the Johannine theology of 'being in the world' without 'being of the world', for the Pope, those for whom 'the life of the church turns into a museum piece or something which is the property of a select few' (Evangelii gaudium 95) suffer from one of the many forms of 'spiritual worldliness', 'which hides behind the appearance of piety and even love for the church' and 'consists in seeking not the Lord's glory but human glory and personal wellbeing' (Evangelii gaudium 93). This disease of the spirit can only be cured 'by making the church constantly go out from herself, keeping her mission focused on Jesus Christ, and her commitment to the poor [...] by breathing in the pure air of the Holy Spirit who frees us from selfcenteredness cloaked in an outward religiosity bereft of God' (Evangelii gaudium 97). Hence the criticism about an academic world that finds all sorts of excuses not to be close to the poor (cf. Evangelii gaudium 201), and the invitation to replace 'desk-bound theology' with a theology that is 'in dialogue with other sciences and human experiences' (Evangelii gaudium 133).

Evangelii gaudium does not repudiate the earlier pronouncements of the CDF; in fact, when Pope Francis affirms that 'for the church, the option for the poor is primarily a theological category rather than a cultural, sociological, political or philosophical one,' he shows to give serious considerations to any legitimate concern of the CDF; yet it represents an

\footnotetext{
40 This should suffice to understand that the question developed in BOFF, C. M. Volta ao fundamento: replica, p. 6, in which the author wonders whether it is Christ or the poor who offers the first perspective for the understanding of the Christian faith, has been put in the wrong way.

${ }_{41}$ In line with SOBRINO, J. El principio-misericordia.
} 
authoritative recognition of what the Latin American theology have been affirming on the church, the poor and theology since the post-conciliar period. ${ }^{42}$ In a way, the words 'continúe escribiendo' (Cf. FANTI, 2015) 'keep writing,' addressed to Jon Sobrino by the Pope in Rome in November 2015, on the occasion of the celebration of the fiftieth anniversary of the Pact of the Catacombs, can be considered a sign of this new trust expressed by the magisterium through $E G$.

\section{The decisive reasons at the basis of the centrality of the poor in the life and Theology of the Church and the proposal of three new possible theological developments}

The witness of the Holy Scripture and the recent development of the teaching of the magisterium, supported by theological reflection, trace the origin of the special and active role that the poor play in the life and the theology of the church to the inner nature of God, which manifested itself in the mystery of Christ. In consideration of these data, first of all we propose a synthetic vision of the reasons behind the origin in God of this privilege of the poor-which constitute the fundamental ground both for the church to choose to 'be poor and for the poor' and for theology to carefully consider the context from which it is elaborated-highlighting the risks that would be met by ignoring or misinterpreting these reasons. Afterwards, hoping for the situation inaugurated by the Evangelii gaudium to be a new impetus to research, we offer a new theological contribution by developing three points of reflection, the first being of theological nature, the second of eschatological nature, and the third of ecclesiological nature.
2.1 In a world marked by sin, sharing our life with the poor is the privileged way of experiencing the intimate life of the Triune God

The incarnation, life, passion, death and resurrection of the Son of God reveal that God is love (cf. Jn 4,8), that is, God in himself is not stasis but ecstasy, going out of oneself as selfgiving to the other. This ad intra ecstatic love has allowed an ad extra ecstatic love, in particular, the creation of beings capable of welcoming this love by giving themselves in turn, which stands at the origin of the possibility of having that interaction among free beings, that is, the origin of the history of salvation. However, the totality of the Christological event also reveals that in the history of salvation the divine love has met with rejection from the human being; that is why, if it is true that history is the place of the signs of the times, that is, a theological place where God lets Himself be encountered by the human being, it is also true that, among these signs, the sign of Jonah stands out, the Easter event (cf. Mt 12:3940), the synthetic sign of the divine love, where the moment of the cross offers the last image of Christ indiscriminately visible to the eyes of all. In this sign of Jonah, the divine love manifests itself as a crucified and risen love that cannot be fully met outside the historical sign of suffering, which is expressed in history, in the most consistent way, right by the vast world of the poor (Cf. GUTIÉRREZ, 1972, p. 204). Therefore, it is precisely through human love as 'conversion to the other', and specifically 'to the oppressed', that the church becomes, in following her Lord, the sacrament of Trinitarian love as movement of 'going out of oneself'. 43 This at least reveals two temptations for the Christian community: on the one hand, the temptation to put in place an option for the poor but without love, which would be completely distorted, since 'if I give all my possessions to feed the poor [...] but do not have love, it profits me

\footnotetext{
42 In Veritatis Gaudium 4, the apostolic constitution on ecclesiastical universities and faculties, drawing on Laudato Si' 49, the Pope will affirm that the first of 'the fundamental criteria for a renewal and revival of the contribution of ecclesiastical studies' must put together the 'joyful and life-giving contemplation of the face of God, revealed in Jesus Christ' and 'the imperative to allow our hearts and minds to heed the cry of the earth's poor,' in fact 'the option for those who are least... must pervade the presentation and study of Christian truth.' 43 We must courageously say, together with SOBRINO, J. No Salvation outside the Poor, p. 90, that the poor constitute 'articulus stantis vel cadentis ecclesiae.
} 
nothing' (1Cor 13:3); on the other, the temptation to deny one's own vocation by carving out, for herself, a presumed transhistorical space, safe from the crucified humanity, which would end up trapping her in a form of spiritual worldliness; in fact, in the light of Christian revelation, the search for a transcendence outside of history is nothing more than withdrawing into oneself, that is, masked selfishness. Of course, it would be interesting to try to understand why, over the centuries, the second temptation seems to have been the most difficult to overcome.

It goes without saying that there are important implications for theology as well. The more theology takes root in the world of the poor, the more easily it is in harmony with the revelation. In fact, as we have shown, 'the epistemological centrality of love refers to the epistemological centrality of the poor' (GIRARDI, 1986, p. 249). Obviously, the perspective of the poor 'is not the only perspective, but it is an indispensable perspective'.44 It should now be clear that there is no 'such thing as an autonomous, impartial academic theology floating free above the realm of human options and biases. However academic it may be, theology is intimately bound up with the psychological, social, or political status quo though it may not be consciously aware of that fact' (SEGUNDO, 1976, p. 13). Consequently, theology is also called to overcome the two temptations we were talking about, avoiding being transformed into an ideology that tries to legitimize political designs or ecclesiastical privileges.

\subsection{A contribution to theo-logy: the poor represent the privileged place to understand divine simplicity}

Let us now present our first new contribution, that of a theological nature, which focuses on the possibility that the poor offer the best way to understand the classical attribute of divine simplicity. This attribute, with which theological tradition has always characterized the divine nature, ${ }^{45}$ represents for Thomas Aquinas the first of the attributes of God. ${ }^{46}$ This attribution has been motivated by the transcendence of God above all created realities, of which He constitutes origin and end; in fact, such transcendence implies that His being cannot be composed of parts. Now, if we consider the divine essence starting from the revelation of the Triune God in the paschal mystery, instead of considering it starting from creation, the attribute of simplicity assumes a different meaning. In the paschal mystery, God reveals himself simply as love and nothing but love (Cf. MARANGI, 2011, p. 402-412). There is nothing in the paschal event that allows us to think of a God who devises convoluted plans of salvation centred on the crucifixion of his Son-as soteriology and preaching often didwhich cannot be the expression of the pure and simple self-giving of divine love. If, from the New Testament onwards, the attempts to 'explain' the cross are multiplied, it is only to make the effectiveness of this saving event intelligible for every generation of Christians, but God, in his absolute simplicity, remains simply self-giving which, because of sin, historically takes the form of Jesus' crucifixion and resurrection. Throughout the centuries, saints with their choice to follow Christ have been clear living witnesses to this being of God. Unfortunately, not all of us get the opportunity to personally meet a saint, but we can all meet the poor. In the impoverished masses of humanity, life in all its facets is so reduced to its essentiality, and so distressed as to let emerge the real nature of the human being created in the image and likeness of Christ. In fact, the poor reveal the essence of humanity, in its absolute simplicity, as radical need for love and capacity for total self-giving. We are not saying in any way that the poor are holy for the simple fact of being poor, unfortunately they too are 'shut up in disobedience' (Rm 11:32), and sometimes their own simplicity turns against them, making them victims of terrible manipulations such as the

44 This is how Pedro Trigo expresses himself in VIGIL, J. M. (Ed.). Getting the Poor Down from the Cross, p. 299-300.

45 The Fathers of the church who have dealt with the topic are the followings: Origen, Gregory of Nyssa, Gregory Nazianzen, Basil, and before them, Philo of Alexandria and Plotinus (cf. Gregory of Nyssa, , 2014, p. 788.

46 Thomas Aquinas, S. Th., I. q. 3. especially a. 7. 
one resulting in the Rwandan genocide of 1994. However, this should not obscure the fact, far more evident and confirmed by the daily experience of those who become their friends, that their 'way of being' has the privilege of constituting, at least 'formally', the living, historical expression of what is closer to the very way of being of God in his manifestation, to the human being, as simple agape. In other words, the personality of God, ${ }^{47}$ of that Thou whom every person meets in prayer and who is manifested in Christ as simple self-giving, analogously finds in the simplicity of the poor its most common correspondent in the world. 'God is like them'. After all, in the Matthean Beatitudes it is precisely the poor, with and for the spirit, that are the pure in heart to whom the vision of God will be disclosed (cf. Mt 5:8).48

\subsection{A contribution to eschatology: the poor constitute the main place from which the hidden lordship of Christ extends into history}

Our second new contribution, that of an eschatological nature, concerns the possibility that the poor have the historical mission of leading humanity towards the eschatological consummation of the Kingdom. The eschatological reality of the Kingdom already belongs to the poor (cf. Mt 5:3; //Lk 6:20; Mk 10:14; //Mt 19:14; //Lk 18:16), who are the first recipients of the message of Jesus, together with 'the persecuted for the sake of justice' (Mt 5:10). If theological reflection has dealt on several occasions with the topic of the relationship between the church and the Kingdom of God, providing clarification statements, ${ }^{49}$ it has not yet paid sufficient attention to the significance of Jesus' affirmations of the possession of the kingdom by the poor and the little ones already in the present era. If the poor already possess the
Kingdom, it is because this is now a reality present in history (cf. Mt 4:17; //Mk 1:15; Mt 10:7; 12:28; //Lk 11:20; LK 10:11; 17:21). This is not in contradiction with the fact that the definitive overcoming of the causes that affict them belongs to the future as the Beatitudes attest, since the kingdom is anyway an inconspicuous reality in the present (cf. Mt 13:31-32; //Mk 4:30-32; //Lk 13:18-19; Mt 13:33; //Lk 13:20; Mk 4:26-29; Lk 17:20). However, one cannot think that this possession in the present is a purely formal fact, devoid of consequences in history, if only because the gospels associate an announcement of bliss with it. The fact that the Kingdom of God does not manifest itself impressively in the present is perhaps the greatest objection raised to Jesus by his contemporaries (cf. Mt 11:3; //Lk 7:19; Mt 12:39; //Mk 8:12; Mt 16:4; //Lk 11:29). The most convincing answer that can be given to this objection is that 'the Lord hath reigned from the tree,'50 that is, the power by which the kingdom becomes established has nothing coercive (cf. Zech 4:6) because it is the power of the nonviolent love fully entered into history through Christ's death and resurrection (cf. Col 1:13-14). We now have enough arguments to state that one of the fundamental places from which the crucified and risen love wields its power in history is precisely that of the poor, both the simply poor we find in Lk and the poor 'with or for the spirit' we find in Mt. On the one hand, the suffering and oppression of the poor are mostly the place in which the risen but crucified love judges the present world and makes it possible to imagine the future world without compromises. ${ }^{51}$ On the other hand, their hope 'against all hope' (Rom 4:18) and their unarmed struggle are mostly the place where the crucified but risen love proves itself invincible (cf. Jn 16:13) and achieves its

\footnotetext{
47 By God's personality we mean 'the essence of God as knowing and willing in analogy with the characteristics of the human personality,' in Lessico di Teologia sistematica, s.v. 'Personalità in Dio,' p. 498.

48 Cf. MAGGl, A. Padre dei Poveri, p. 128-129. While for the Psalm 24 purity of heart is just one of the requisites to participate in the worship inside the temple, for Mt 5:8 the attitude of the pure of heart, fruit of adherence to the evangelical ideal proposed by the Beatitudes renders superfluous any cultural or ritual mediation to access the vision of God.

49 Cf. Lumen gentium 3; 5; Redemptoris Missio 20; INTERNATIONAL THEOLOGICAL COMMISSION. Temi scelti di ecclesiologia (1985), 10.2. 50 Justin Martyr, The First Apology, p. 41; cf. also Vexilla Regis: 'God has reigned from the tree.'

51 When we approach the poor and establish relationships based on that ontological poverty that unites human beings, we begin to question the causes of their poverty, and in so doing we begin to have a different vision of reality, to discover for example-as does CASTILLO, J. M. I poveri e la teologia, p. 288-that it is not possible objectively [...] to take seriously Christian faith without taking sides [...] against economic neoliberalism.' The immigration from impoverished countries to impoverishing countries is today one of the ways in which the Crucified calls on humanity to achieve a better world.
} 
victory over the world of $\sin .^{52}$ We can therefore conclude that the poor in some way exercise a real lordship in history, associated with the lordship itself of Christ. If this lordship does not seem to be effective enough, it is because it acts through that same force in the weakness by which Christ brings about redemption and which is opposed by all other forms of power. ${ }^{53}$ It is revelation itself that in different ways supports this lordship of the poor, which will be fully revealed with the lordship of Christ on the last day. They are in fact those who 'shall laugh' (Lk 6:21); and at the coming of the Son of man, the attitude adopted by all peoples towards them will be the ultimate criterion of judgment. Even ancient African Christianity had perceived it. In fact, following the early Christian community who in the light of the paschal mystery sees in the cross the place of the eschatological judgment of God on the world, it assigned to the poor the task of making effective this judgment of the cross on the last day. ${ }^{54}$ Recently, John Paul II went so far as to express himself with these words:

In the light of Christ's words, this poor South will judge the rich North. And the poor people and poor nations-poor in different ways, not only lacking food, but also deprived of freedom and other human rights-will judge those people who take these goods away from them, amassing to themselves the imperialistic monopoly of economic and political supremacy at the expense of others. ${ }^{55}$

Detecting the datum of the lordship of the poor associated to that of Christ can offer important directions, even politically, especially at a time when the discourse on the poor as a theological place risks becoming exclusively sapiential, losing the prophetic-eschatological tones that had characterized its entry into theology, due to a certain disillusionment that succeeded a new kind of 'delay of the Parousia,' namely, the nonfulfillment of the oppressed peoples' expectations of liberation at the beginning of the second half of the last century. ${ }^{56}$ The poor perform a real messianic task in history, depending on that of Christ. They are entrusted by God with a certain leadership of humanity, which they will exercise until Christ delivers the Kingdom to the Father (cf. 1Co 15:24), through a power that shows its effectiveness not through armed coercion but through disarming persuasion, which anyway does not establish itself without entering into conflict with the realities in which sin is embodied.

\subsection{A contribution to ecclesiology: the poor offer the church the necessary help for her to be better and better the mystical body of christ in history}

The third point of reflection is of an ecclesiological nature and concerns the possibility that an authentic relationship of the church with the poor ${ }^{57}$ can cure her of clericalism, which has been defined as one of the perversions that make

\footnotetext{
52 I will never forget the strength to fight that I received in Nairobi from the testimony, of faith and hope, of a Luo woman dressed in red at the altar of an outstation of the parish, in front of the coffin of her 15-year old daughter, dead of meningitis and tuberculosis in a shack in the Deep-Sea slum, on a rain-soaked mattress. In reality it is not liberation theology that makes of violence and war 'the engine of history' ( $L N I X, 3)$, but all those who have the grace to exercise the power of active non-violence and renounce it.

53 This entails a price to pay, the 'price of the messianism', that is, 'the price of staying low in history.' an idea re-elaborated by CASTILLO, J. M. I poveri e la teologia, p. 379 starting from the conclusions of the classic essay SCHOLEM, G. Concetti fondamentali dell'ebraismo, p. 107. 54 In the 'stauros' homily from a Nubian Christian Community of the $\mathrm{X}$ century. Jesus, on his return for the judgement, will have the symbol of the cross with him, will not judge the peoples according to the law but will test their faith in the cross which will be revealed especially by their attitude towards the needy (cf. Mt 25:35-36) (cf. GRIFFITH, 1913, p. 41-53).

55 Homily during the Mass at the Namao airport (Edmonton, Canada), September 17, 1984, nos. 3-4, quoted by GUTIÉRREZ, G.; MÜLLER, L. On the Side of the Poor, chap. 5. The words of John Paul II appear as a paraphrase of Mt 12:41-42; //Lk 11:31-32; other biblical passages that allude to some participation of others in the eschatological judgment of Christ are the following: Mt 19:28; //LK 22:30; 1Co 6:2-3; Rev 3:21; 20:4). ${ }_{56}$ In spite of everything. Ellacuria does not renounce the historical-eschatological dimension of reflection on the role of the poor in the church and theology, as evidenced by his last speech given in Barcelona on November 6, 1989, in which he speaks of the need 'to try, along with all the poor and oppressed people of the world, to reverse history, to subvert it and thrust it in another direction' (SOBRINO, 2008, p. 35). 57 For example, the type of relationship with the poor proposed to the whole church by EG. In Africa, UZUKWU, E. A Listening Church, p. 127-129 has proposed an ecclesiological model that restores ecclesial protagonism to poor populations, which is inculturated in the local reality and has been define by the author as the model of 'the church with long ears' or of the listening church. This image comes from the rabbit totem adopted by the head of the Manja tribe in the Central African Republic; at the base of this choice there is the conviction that for the chief to be fair he must be a patient listener. According to the Bambara philosophy, shared by the population Manja, 'the Word which saves and heals' is 'too large for an individual mouth,' 'no speaker ever totally masters or appropriates it,' therefore in the life of the community it is necessary 'the liberation of word at all levels of community.' that is achieved through the prolonged and careful listening of each and every one before any decision is taken; anyway, this is the methodology of the Palaver spread among many populations of Sub-Saharan Africa.
} 
the Christian community sick. ${ }^{8}$ 'Clericalism is related to secularism and both concepts reflect the intra-ecclesial and extra-ecclesial relations between clergymen and those who are not, that is, laymen.' In particular 'by clericalism we generally mean transformation and reduction of faith in an instrument of power' (BADA, 1998, p. 7-8). Let us begin our reflection by briefly examining the theological reality of ecclesial communion. CVII allowed the passage from a juridical ecclesiology to a communion ecclesiology (cf. Christifideles laici 19). The reality of ecclesial communion, which primarily refers to the invisible and divine dimension of the church, that is 'the communion with God through Jesus Christ in the Holy Spirit' (THE SECOND EXTRAORDINARY COUNCIL OF THE SYNOD OF BISHOPS, 1985, II, C, 1) and should not be confused with 'some kind of vague disposition' (Lumen gentium, Preliminary Note of Explanation 2), cannot be achieved by simply joining with Christ in the Catholic church 'by the bonds of the profession of faith, the sacraments, and ecclesiastical governance' (Code of Canon Law 205). In fact, Lumen gentium 14 specifies that

Fully incorporated into the church are those who, possessing the Spirit of Christ litalics are ours], accept all the means of salvation given to the church together with her entire organization, and who-by the bonds constituted by the profession of faith, the sacraments, ecclesiastical government, and communion-are joined, in the visible structure of the church, with Christ.

It also states that the simple incorporation of one who 'does not persevere in charity' is useless, since he or she 'remains indeed in the bosom of the church, but only 'in body' and not 'in heart'. In this way the dogmatic constitution on the church presents an ecclesiological vision into which it is possible to integrate the result of the journey accomplished by exegesis, theology and the magisterium, from the post-conciliar period up to this day, according to which an authentic relationship between the church and the poor is indispensable for her to fully be a sacrament of the Trinitarian love, and therefore fully become an expression of the divine communion in history. ${ }^{59}$ Unlike Lumen gentium, the second chapter of preparatory scheme De Ecclesia left out any reference to charity or the Holy Spirit, and considered the subjection to hierarchy as an indispensable condition even for the simple belonging to the church, although it recognized the action of the same Spirit beyond the confines of the ecclesial body. ${ }^{60}$ This was possible because, for a certain ecclesiological tendency, quite dominant even at the time of the council, to say 'the church is generated from above' could only mean that 'the church is generated by the hierarchy.' ${ }^{61}$ This ecclesiology, to which Congar himself ended up giving the name of a hierarchiology, ${ }^{62}$ was one of the consequences of a process started by Constantine as early as the IV century. In fact, with his choice to progressively confer on Christianity the privileges of a state religion, it became increasingly difficult for the clergy to resist the temptation of power, both

58 Cf. FRANCESCO. Incontro con il clero, i religiosi e i seminaristi. Discorso del Santo Padre Francesco, cattedrale (Palermo), Sabato, 15 settembre 2018: 'The church is not above the world, this is clericalism, the church is inside the world, to make it ferment, like leaven in the dough. For this, dear brothers, every form of clericalism must be banned, it is one of the perversions that are most difficult to remove today.' 59 From an ecclesial point of view, the concept of communion should never be understood regardless of the image of the People of God who historicises it, cf. PHILIPS, 1967, p. 51, 99, 120; COMBLIN, 2007, p. 113-130. According to Sobrino, for the ministerial centres of ecclesial communion, that is the various institutional centres of the church, to lend their irreplaceable service, it is necessary that they welcome, learn and thank the real centres of the ecclesial substance, that is, the places where ecclesial communion becomes a real fact, or even better, the places where the communion with the world of crucified peoples is realised and 'those who are below' are together with 'those who abase themselves'; cf. ELLACURIA; SOBRINO, 1992, p. 705-725.

6o Cf. ACERBI, A. Due ecclesiologie, p. 117-122 and 502; PHILIPS, G. La Chiesa e il suo mistero nel Concilio Vaticano II, p. 22, which sees in the Council the transition from the church as a power to the 'domain of Christian charity' (expression used by John XIII in Solenne apertura del Concilio Ecumenico Vaticano II discorso del Santo Padre Giovanni XXIII, giovedi, 11 ottobre 1962).

${ }_{61}$ Cf. SCHEEBEN, M. J. I misteri del Cristianesimo, p. 401-410, whose first edition in German dates back to 1865: JOURNET, Ch. L'église du Verbe incarné, v. 1, p. 24-62; CONGAR, Y. Per una teologia del laicato, p. 144 and 499; and the conciliatory speech by Pope Paul VI during the conciliar session of September 14, 1964, in ACERBI, A. Due ecclesiologie, p. 437-439.

62 CONGAR, Y. Le Concile de Vatican II, p. 124. Möhler's ironical observation, in his critical review of Theodor Katerkamps's study on church history, has remained famous: 'God has created the hierarchy and so has shown more than enough care for the church until the end of the world' (MÖHLER, 1823, p. 497). 
for the benefits it gave access to, ${ }^{63}$ and because it could be useful, in its eyes, to carry out the mission with which the divine Founder of the church had invested it.64 To get an idea of the devastating outcomes that ensued from this alliance between empire and priesthood, which is at the origin of the problem of clericalism to this day, it may suffice to recall that almost all the great social movements of the Western world, from the late Middle Ages, have had an anticlerical character. ${ }^{65}$ Furthermore, missionary activity often turned into a route of cultural colonization of nonEuropean populations, since the church's attempt, through the clergy, to assume a hegemonic role in the old continent, with the aim of exercising the function of intellectual and moral direction, led her to identify herself with the culture of the ruling classes, and consequently to impose it on the peoples to be evangelized. ${ }^{66}$ In any case, the final text of Lumen gentium, despite revolving around the concept of communion, is not able to definitively move beyond a vertical and pyramidal ecclesiology that puts an end to all forms of clericalism, since the ministry is still described in terms of power (potestas) ${ }^{67}$ without further specifying the nature of this power. ${ }^{68}$ Since this power is a participation in that of Christ (cf. Lumen gentium 19; 27; 35), it must be of the same nature as the power exercised by Christ in his life, passion, death and resurrection. ${ }^{69}$ History has shown that the simple reference to the fact that 'the sacred power' should be exercised in a spirit of service, insistently reported by the text of Lumen gentium (cf. Lumen gentium 18; 24; 27; 28; 29; 32; 41), has ended up having a purely rhetorical function, ${ }^{70}$ all the more so because the Lord's saying about the necessity for the leadership of the Christian community to be the servant of all (Mt 20:26-28; //Mk 10:43-45; //Lk 22:26-27) is unduly interpreted in an exclusively figurative sense, ${ }^{71}$ and separated from the previous saying, to which it is syntactically bound, namely, the one in which the Lord categorically excludes that the leadership of the Christian community can

\footnotetext{
${ }_{63}$ Cf. the clear perception of this danger that Hilary of Poitiers had: 'On the horizon there is a treacherous persecutor, an enemy who flatters, does not scourge our back, but caresses our womb, does not confiscate our goods, but makes us rich; he does not imprison us by pushing us towards freedom, but he honours us in the palace, pushing us to slavery; he does not tighten our hips with chains, but wants the possession of our heart; he does not cut off our heads with his sword, but he kills our souls with money, power, success, the first places in our society:' (Hilary of Poitiers, Contra Costantium 5 ).

${ }_{64}$ For LAFONT, G. Histoire théologique de l'église catholique, p. 120, the Neoplatonist mysticism of the 'One' also played an important role. 65 Among these movements, we can chronologically mention the followings: the heretical movements from the XI to the XIII century, the movement of the Lollards, the Hussite movement, the Protestant Reformation especially in the instances raised by Thomas Müntzer, the Anabaptist movements, which inspired the constitution of the United States of America, the French Revolution; the bourgeois revolutions of the XIX century; socialism, and secularism (Cf. COMBLIN, 2007, p. 57-79).

${ }_{66}$ Cf. GIRARDI, G. La tunica lacerate, p. 94-98.127-128. For ODUYOYE, M. A. Hearing and Knowing. p. 115: 'The church in Africa and especially the Western churches (Roman Catholic, Anglican Lutheran, Methodist, Baptist, Presbyterian) have a very middle-class profile. Church architecture, vestments, and interior decoration (including luxurious pipe organs) do not provide an atmosphere that is welcoming to the majority of African Christians. Yet all this is said to derive from the idea of worshipping in the beauty of holiness.'

67 Cf. Lumen gentium 10:18:22: 24:27:28: 35: Preliminary Note of Explanation 1: 2: 3: 4: 5 . The consequence is that, while in Jn $15: 15$ we read of Jesus saying. 'No longer do I call you servants [...] but I have called you friends,' Lumen gentium 27, Preliminary Note of Explanation, and above all Canon Law make use of the term 'subject' to describe relationships within the ecclesial community. New Testament never resorts to similar terms, even though there are invitations to submission, expressed through the verb úmotó $\sigma \sigma \omega$, addressed to very heterogeneous subjects and realities (cf. Lk 2:51; 10:17; Rm 8:20; 13:1; 1Co 14:34; 15:27-28; 16:16; Ep 5:21.24; Tt 2:9; 3:1; Heb 12:9; 1 Pt 2:13.18; 5:5). 68 In any case, it is Evangelii gaudium 104 itself that highlights how the danger of closely identifying 'sacramental power [...] with power in general' is all but non-existent.

${ }_{69}$ Cf. Lumen gentium $3 ; 7 ; 24 ; 35 ; 36 ; 44$. To this end, neither the contribution of the studies on historical Jesus nor the theology of the Paschal Mystery should be neglected. ODUYOYE, M. A. Hearing and Knowing, p. 143, starting directly from the Trinitarian dogma, goes so far as to affirm that 'our baptism into the name of the Trinity means that we should not stand for monarchies and hierarchies but rather for participation. In God's economy we find a sharing of power and of responsibility. The result of action is attributed to all three persons.' 70 Lk 22:25 recognizes this possibility by referring to those in authority over the nations who are called benefactors. Indeed, the fact that the popes called themselves Servi Servorum Dei did not prevent the abuse of power in the history of the papacy, such as the one which gave rise to the Western Schism from 1378 to 1417.

71 It should be noted that some gospel passages suggest that there is no way of serving while remaining externally 'first:' according to Mk 9:35, the first must indeed become the last; according to Mt 20:27 and // Mk 10:44 the one who wants to be the first should not simply

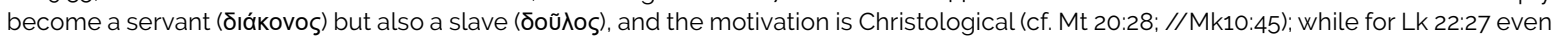
the external form of the one who serves must conform to that of one who in society occupies the lower rank.
} 
exercise the same power as 'the leaders of the nations' (cf. Mt 20:25; Mk 10:42; Lk 22:25; 1 Pt 5:3).72

Now, it seems that the Lord himself took care to show his church and her leaders the sure way to defeat the perversion of clericalism. To illustrate this way, we can use an example taken from the history of the elaboration of the conciliar documents during VCII. If one examines the troubled path that led to the writing of chapter III of the Lumen gentium, in which the council fathers defined the complex relations existing between the Pope and the episcopal college, or the Pope and the individual bishops, and which ended only with the inclusion of the Preliminary Note of Explanation in the final document, one gets the impression of being at that gospel scene where the Twelve 'had argued with one another about who was the greatest' (Mk 9:34; cf. Lk 9:46; 22:24) almost heralding the evil of clericalism that would arise in the future of the church. ${ }^{73}$ In that episode, the saying about the necessity for the leaders of the community to take the role of the servant, in its exemplified form (cf. Mk 9:35; Mt 23:11; Lk 9:48), is followed by an action of Jesus which constitutes its concrete interpretation. Jesus takes a child-who, as we have seen, is an authoritative representative of the poor peopleplaces her in the middle-a place that is normally reserved for Jesus in the gospels (cf. Mt 18:20; Lk 2:46; Lk 24:36) - and embraces her declaring that those who welcome such children in his name welcome Jesus himself and, actually, the very One who sent him (cf. Mt 18: 5; Mk 9:37; Lk 9:48). The gesture of embracing, which is found

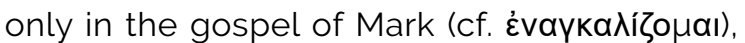
together with the invitation to welcome can be considered a plastic expression of the relationship with the poor that Pope Francis recommends.
According to this passage of the gospel, this relationship is not a relationship in which the poor are considered exclusively an object of Christian charity, but a relationship in which the leaders of the Christian community are called to offer them the first places in the church, to heed them, to take on their suffering by becoming one body with them. Thus, the antidote to clericalism offered ante litteram by the episode of the gospel of Mark suggests us that the poor can allow the church to be more faithfully the presence of the mystical body of Christ in history especially by helping those who have the task of leading the church, enable them to remain more faithful to their vocation of servants of the community.

\section{'You will always have the poor with you' (Mt. 26:11)}

With the previous three reflections on the contribution that the poor can offer for a deeper mystical knowledge of God in the world, for a more forward-looking political commitment of Christians in history, and for the implementation of a more authentic communion in the church, we close our study on the journey of the rediscovery of the role played by the poor in the mystery of redemption, travelled by the entire ecclesial community from the Council to present day. The results of this investigation make us conclude that the more the church's hour will be the hour of the poor, the more it will be eschatological. The possibility, indicated by 2Pt 3:12, of 'hastening the coming of the day of God' (cf. Acts 3:20; Mt 6:10) has always had a certain fascination for Christians. The more the church of Christ will be the church of the poor according to her glorious icon, Mary, who stands out among the humble and the poor of Yhwh (Lumen gentium 55), the more

\footnotetext{
72 According to RATZINGER, J. Das neue Volk Gottes, p. 273, when the followers of the apostles considered it right to be the principles of this society with the Constantin shift, and transgressed the commandment contained in this saying of the Lord, they made a return to the pre-Christian and pagan situation. It is interesting to note that in this passage, the 4 verbs used by the synoptics, namely katakupıє́ $\omega$,

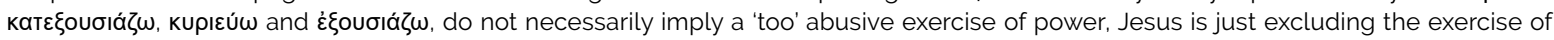
earthly power. When Lumen gentium 27 states, 'Bishops, as vicars and ambassadors of Christ, govern the particular churches entrusted to them by their counsel, exhortations, example, and even by their authority and sacred power,' should we consider this sacred power to be none other than the power of the weakness of the cross?

73 This impression is also confirmed by the fact that in the description Lumen gentium 25-27 makes of the bishops' tasks there is 'insufficient consideration of the bishop's relationship with the faithful and of their role in the exercise of episcopal functions, unlike what we would expect after the chapter on the people of God' (ACERBI, 1975, p. 404). About 'the atmosphere bristling with suspicions and polemics' that led to the decision to elaborate the Explanatory Note Previa (cf. ACERBI, 1975, p. 460-474).
} 
she will rush towards her fulfilment in the future age (cf. Lumen gentium 68). In this perspective, Evangelii gaudium truly represents the opening of an era of greater awareness, in the history of the church, of her vital link with the poor, which must result in a greater decentralization, even at a geographical level, whereby the oldest churches, who live in the richest areas of the globe, must be more open to listening to the voices rising from the poorest areas of the globe, recognizing, for example, that today Africa constitutes 'one of the places where God will speak to the church and to humanity.'74 The saying of the Lord 'You will always have the poor with you but you will not always have me,' especially in the context of the gospel of Mt (cf. Mt 26:11; //Mk 14:7; Jn 12:8) (Cf. THEOHARIS, 2017) can summarize this renewed ecclesial acquisition. These words of Jesus do not have the slightest intention of demobilizing the commitment of Christians in the struggle against poverty in the world, as evidenced by their reference to Deuteronomy which states that the permanence of misery in Israel is not a divine will but a consequence of human disobedience (cf. Dt 15:4.11; Acts 4:34). On the contrary, the tension between 'you will not always have me' in Mt 26:11, and 'I am with you always, to the end of the age' in Mt 28:20, especially if we do not forget the picture of the final judgment (cf. Mt 25:31-46), prophetically hints at the irreplaceable historical-salvific mission that the poor carry out in the eschatological present for the benefit of the community of Jesus' disciples until the Parousia. 'You will always have the poor with you' is thus the announcement of a grace that can save humanity from its greatest misery - the spiritual one.

\section{REFERENCES}

ABBLE, Albert et al. Des prêtres noirs s'interrogent. Paris: Les Editions du Cerf, 1956.

ACERBI, Antonio. Due ecclesiologie. Bologna: Edizioni Dehoniane, 1975.

ASSMANN, Hugo. Teologia desde la praxis de la liberación. Salamanca: Sigueme, 1973.
BADA, Juan. Il clericalismo e l'anticlericalismo. Milano: Jaka Book, 1998.

BOESAK, Allan Aubrey. Farewell to Innocence. New York: Orbis Books, 1976.

BOFF, Clodovis M. Volta ao fundamento: replica. Revista Eclesiástica Brasileira, [S. l.], v. 68, n. 272, p. 1-22, 2008 https://doi.org/10.29386/reb.v68i272.1413.

BOFF, Leonardo. Igreja: carisma e poder. Petrópolis: Vozes, 1981

BONHOEFFER, Dietrich. Letters and Papers from Prison. Edited by Eberhard Bethge. New York: Touchstone, 1971.

BROWNE, Maura; AFRICA FAITH AND JUSTICE NETWORK (ed.). The African Synod: documents, reflections, perspectives. New York: Orbis Books, 1996.

CASTILLO, José Maria. I poveri e la teologia. Assisi: Cittadella Editrice, 2002.

CHENU, Marie-Dominique. La parole de Dieu. Vol. 1, La foi dans l'intelligence. Paris: Éditions du Cerf, 1964.

COMBLIN, José. Il popolo di Dio. Troina: Servitium Editrice, 2007.

CONE, James H. A Black Theology of Liberation. Philadelphia: Lippincott, 1970.

CONE, James H. God of the Oppressed. New York: Seabury Press, 1975.

CONGAR, Yves. Le Concile de Vatican II. Paris: Beauchesne Éditeur, 1984.

CONGAR, Yves. Per una teologia del laicato. Brescia: Morcelliana, 1966.

CONGREGATION FOR THE DOCTRINE OF THE FAITH. Notification on the book 'Church: charism and power' by Father Leonardo Boff OFM, 1985. Available at: http:// www.vatican.va/roman_curia/congregations/cfaith/ documents/rc_con_cfaith_doc_19850311_notif-boff_en.html. Access on: 14 Dec. 2018

COSTADOAT, Jorge. El lugar en Jon Sobrino. Theologica Xaveriana, n. 181, p. 23-49, 2016. Retrieved on: 12 Dec. 2018. https://doi.org/10.11144/javeriana.tx66-181.ltjs.

ÉLA, Jean-Marc. Cri de l'homme Africain. Paris, L'Harmattan, 1980

ÉLA, Jean-Marc. My Faith as an African. Oregon: Wipf and Stock, 2009.

ELLACURÍA, Ignacio et al. Fe, justicia y opción por los oprimidos. Bilbao: Editorial Deslée de Brouwe. 1980.

ELLACURIA, Ignacio; SOBRINO, Jon (ed.). Mysterium Liberationis. Milano: Borla 1992.

ELLACURÍA, Ignacio. Conversione della Chiesa al Regno di Dio. Brescia: Editrice Queriniana, 1992.

74 This is how Jean-Marc Éla expresses himself in BROWNE, M.; AFRICA FAITH AND JUSTICE NETWORK (Ed.). The African Synod: Documents, Reflections, Perspectives, p. 133. 
ELLACURÍA, Ignacio. La iglesia de los pobres, sacramento histórico de liberación. Estudios Centroamericanos, [S. L.], n. 32, p. 707-722, Oct.-Nov. 1977.

ELLACURÍA, Ignacio. Los pobres, lugar teológico en América Latina. Misión Abierta, [S. L.], v. 74, nos. 4-5, p. 225-240, Nov. 1981.

FABRIS, Rinaldo. Matteo: traduzione e commento. Roma: Borla, 1982.

FANTI, Claudia. L'orrore di Parigi e le vittime di tutto il mondo: intervista a Jon Sobrino. Adista.it. 11 Nov. 2015. Available at: https://Www.adista.it/articolo/55679. Retrieved on: 15 Dec. 2018.

FERM, Deane William. Third World Liberation Theology. Oregon: Wipf and Stock Publishers, 2004.

GHIBELLINI, Rosino. La teologia del XX secolo. Brescia: Queriniana, 1996.

GIRARDI, Giulio. La tunica lacerate. Roma: Borla, 1986.

GONZALEZ FAUS, Jose Ignacio. Los pobres como lugar teológico. Revista Latinoamericana de Teologia, v. 1, n. 3. p. 275-308, Sep.-Dec. 1984

GREGORY OF NYSSA. Opere Dogmatiche. Edited by Claudio Moreschini. Milano: Bompiani, 2014.

GRIFFITH, F. Li (ed.). The Nubian Texts of the Christian Period. Berlin: Verlag der königlichen Akademie der Wissenschaften, 1913.

GUTIÉRREZ, Gustavo; MÜLLER, Ludwig. On the Side of the Poor. New York: Orbis Books, 2015. Kindle edition.

GUTIÉRREZ, Gustavo. La forza storica dei poveri. Brescia: Queriniana, 1981.

GUTIÉRREZ, Gustavo. La verità vi farà liberi. Brescia: Queriniana, 1990.

GUTIÉRREZ, Gustavo. Teologia della liberazione. Brescia: Queriniana, 1972.

JOURNET, Charles. L'église du Verbe incarné. Vol. 1. Paris: Desclée de Brouwer, 1941.

JUSTIN Martyr, The First Apology. Edited and translated by Thomas B. Falls. Washington: Catholic University of America Press, 1977.

LAFONT, Ghislain. Histoire théologique de l'église catholique. Paris: Les Éditions du Cerf, 1994.

LESSICO di Teologia sistematica. Edited by Wolfgang Beinert. Brescia: Editrice Queriniana, 1990.

LOIS, Julio. Teología de la liberación: opción por los pobres. Madrid: Iepala Editorial, 1986.

MAGGl, Alberto. Padre dei Poveri. Assisi: Cittadella Editrice, 2008.

MARANGI, Ettore. La resurrezione di Gesù come locus theologicus. Assisi: Cittadella Editrice, 2011.

MESSI METOGO, Éloi. Dieu peut-il mourir en Afrique? Yaoundé: Presses de l'UCAC, 1997.
MÖHLER, Johann Adam. Rezension. Theologische Quartalschrift, v. 5, p. 495-502, 1823

MOORE, Basil (ed.). Black Theology: the South African Voice. London: C. Hurst and Company, 1973.

MOUNIER, Emmanuel. Oeuvres de Mounier. Vol 4. Paris: Editions du Seuil, 1963.

MVENG, Engelbert. Impoverishment and Liberation: a theological approach for Africa and the Third World. In: GIBELLINI, Rosino (ed.). Paths of African Theology. New York: Orbis Books, 1994. p. 154-165.

MVENG, Engelbert. L'Afrique dans l'église: paroles d'un croyant. Paris: L'Harmattan, 1985.

NIRMAL, Arvind Paulus (ed.). Towards a Common Dalit Theology. Madras: Gurukul LTC, 1989.

ODUYOYE, Mercy Amba. Hearing and Knowing. New York: Orbis Books, 1986

PHILIPS, Gérard. La Chiesa e il suo mistero nel Concilio Vaticano II. Milano: Jaca Book, 1967.

RATZINGER, Joseph; MESSORI, Vittorio. The Ratzinger Report. San Francisco: Ignatius Press, 1985.

RATZINGER, Joseph. Das neue Volk Gottes. Düsseldorf: Patmos, 1969

RATZINGER, Joseph. Luther et l'unité de l'Église. La Documentation catholique, [S. l.], n. 81, p. 121-128, 1984.

REVELLI, Marco. La lotta di classe esiste e l'hanno vinta i ricchi. Bari: Laterza, 2014.

ROWLAND, Christopher (ed.). The Cambridge Companion to Liberation Theology. Cambridge University Press, 2007.

SCHEEBEN, Matthias Joseph. I misteri del Cristianesimo Brescia: Morcielliana 1953.

SCHOLEM, Gershom. Concetti fondamentali dell'ebraismo. Genova: Marietti, 1986.

SEGUNDO, Juan Luis. Liberation of Theology. Oregon: Orbis Books, 1976.

SOBRINO, Jon. El principio-misericordia: bajar de la cruz a los pueblos crucificados. Santander: Sal Terrae, 1992.

SOBRINO, Jon. Gesù Cristo liberatore. Assisi: Cittadella Editrice, 1995

SOBRINO, Jon. No Salvation outside the Poor. New York: Orbis Books, 2008.

SOBRINO, Jon. Resurrección de la verdadera Iglesia: Los pobres, lugar teológico de la eclesiología. Santander: Editorial Sal Terrae, 1981.

THE KAIROS DOCUMENT. 1985. South African History Online. Available at: https://www. sahistory.org.za/archive/challenge-church-theological-comment-political-crisis-south-africa-kairos-document-1985. Accessed on: 17 Dec. 2018. 
THE SECOND EXTRAORDINARY COUNCIL OF THE SYNOD OF BISHOPS. Relatio Finalis, 24 Nov.-8 Dec. 1985. Available at: http://www.synod.va/content/dam/synod/documenti/sinodo\%20dei\%20vescovi\%201985\%20 relazione\%20finale.pdf. Retrieved on: 21 Dec 2018.

THEOHARIS, Liz. The poor we have with us. The Christian Century, [S. l.], p. 26-29, Apr. 26, 2017.

Thomas Aquinas. Summa Theologica. Vol. I. New York: Cosimo, 2007.

TUTU, Desmond. J'ai aussi le droit d'exister. Lausanne: Éditions du Soc, 1982.

UZUKWU, Elochukwu E. A Listening Church. New York: Orbis Books, 1996.

VERWEYEN, Hansjürgen. La parola definitiva di Dio. Brescia: Queriniana, 2001.

Vexilla regis prodeunt in Harrington, K. P., ed., Medieval Latin. Chicago: The University of Chicago Press, 1997

VIGIL, Jose Maria (ed.). Getting the Poor Down from the Cross. EATWOT/ASETT, 2007. Available at: http://WWW. servicioskoinonia.org/LibrosDigitales/LDK/EATWOTGettingThePoorDown.pdf. Retrieved on: 14 Dec 2018.

VIGIL, José María. La opción por los pobres es opción por la justicia, y no es preferencial. Theologica Xaveriana, [S. l.], n. 149, p. 151-166, jan. /mar. 2004.

WIEDENHOFER, Siegfried. Ecclesiologia. In: SCHNEIDER, Theodor (ed.). Nuovo corso di dogmatica. 2 vol. Vol. 2. Brescia: Queriniana, 1995, p. 59-179.

WITHERUP, Ronald D. Scripture: Dei Verbum. New York: Paulist Press, 2006.

ZUNDEL, Maurice. Émerveillement et pauvreté. Saint-Maurice: Éditions Saint-Augustine, 2009.

\section{Ettori Marangi}

Doctor in theology at the Pontifical Gregorian University with a thesis on the fundamental and soteriological significance of Jesus' resurrection. He was a lecturer at the Theological Faculty of Puglia in Bari (Italy) and currently teaches Systematic Theology at the Tangaza University College (Kenya).

\section{Mailing address:}

Ettori Marangi

Tangaza University College

Langata South Road, 15055-00509

Nairobi, KE, Kenya. 